\title{
Double pylorus
}

\author{
Simant Singh Thapa, ${ }^{1}$ Jeffrey Scott ${ }^{2}$
}

'Department of Medicine, Saint Vincent Hospital, Worcester, Massachusetts, USA ${ }^{2}$ Pulmonary and Critical Care Medicine, Saint Vincent Hospital, Worcester, MA, USA

Correspondence to Dr Simant Singh Thapa, thapasimant@gmail.com

Accepted 8 August 2018
Check for updates

(c) BMJ Publishing Group Limited 2018. No commercial re-use. See rights and permissions. Published by BMJ.

To cite: Thapa SS, Scott J. BMJ Case Rep Published Online First: [please include Day Month Year]. doi:10.1136/bcr-2018225850

\section{DESCRIPTION}

A 69-year-old man with a past medical history of asthma, chronic back pain and hypertension presented with symptoms of light headedness, epigastric pain and blood-mixed bowel movement of 2 days duration. Since the past 9 months the patient had been taking two to three pills of ibuprofen almost on a daily basis for his back pain. He had also received short courses of prednisone tablets frequently in the last 6 months for his poorly controlled asthma. On arrival in the emergency room, his blood pressure was $84 / 48 \mathrm{~mm} \mathrm{Hg}$, heart rate $121 / \mathrm{min}$, respiratory rate $18 / \mathrm{min}$, temperature $36^{\circ} \mathrm{C}$ and oxygen saturation was $94 \%$ on room air. His haemoglobin $(\mathrm{Hb})$ was $7.2 \mathrm{mg} / \mathrm{dL}$. The patient was given proton pump inhibitor (PPI) therapy, volume resuscitated and was admitted to the intensive care unit. After 2 units of packed red blood cell transfusion his $\mathrm{Hb}$ was $9.1 \mathrm{mg} / \mathrm{dL}$. He underwent upper gastrointestinal (GI) endoscopy which showed two openings into the duodenal bulb, an intact pylorus and a large fistula superior to the pylorus opening into the duodenal bulb (figure 1). The gastroduodenal fistula appeared chronic with no acute ulceration or inflammation. A medium-sized bleeding ulcer with surrounding oedema was noticed in the duodenal bulb. A submucosal injection of epinephrine was performed around the bleeding site and complete haemostasis was achieved by placing a single hemoclip on the bleeding site. Helicobacter pylori test was negative. He was discharged on oral PPI therapy. On the third day from discharge, the patient again had a large blood-mixed bowel movement and there was a significant drop in his $\mathrm{Hb}$ level to $6.6 \mathrm{mg} / \mathrm{dL}$. He

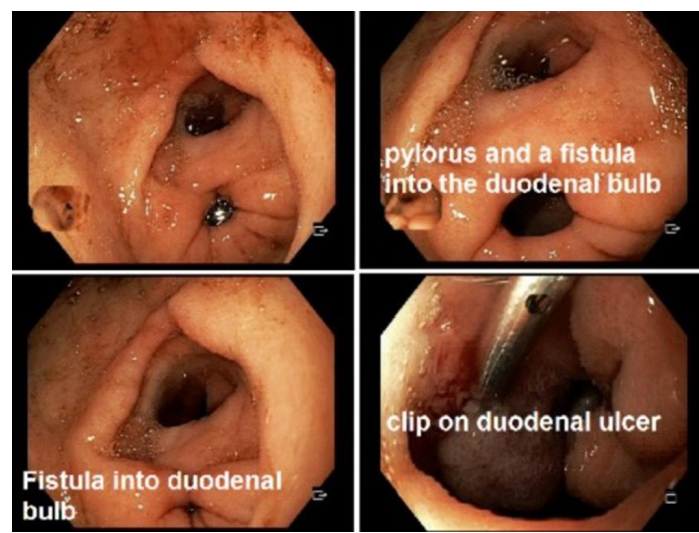

Figure 1 Upper gastrointestinal endoscopy showing two openings into the duodenal bulb, an intact pylorus and a large fistula superior to the pylorus opening into the duodenal bulb. A hemoclip being applied to the bleeding duodenal ulcer. underwent upper GI endoscopy which showed dark clots in the stomach but did not show the active bleeding site. CT angiography was done which also failed to identify the bleeding source. The next day the patient had another large bloodmixed bowel movement, so he underwent midline laparotomy and ligation of the bleeding duodenal ulcer along with pyloroplasty and vagotomy. After the surgery his $\mathrm{Hb}$ remained stable around $9.5 \mathrm{mg} / \mathrm{dL}$ and no further episodes of GI bleeding occurred. On follow-up visit, he had a good recovery and he was pleased with the postoperative results. The gastroduodenal fistula in the patient likely resulted due to unrecognised peptic ulcer disease from chronic ibuprofen intake for back pain and recurrent prednisone short-course therapy for poorly controlled asthma.

The 'double pylorus' is a rare condition due to a gastroduodenal fistula extending from the gastric antrum to the duodenal bulb. It may be congenital or acquired. ${ }^{1}$ Acquired cases can occur in gastric cancer or as a complication of chronic peptic ulcer disease leading to penetration of the peptic ulcer and the formation of a fistula between the duodenal bulb and the prepyloric antrum. It is a rare malformation found in less than $0.4 \%$ of upper GI endoscopy cases. ${ }^{2}$ Recurrent ulcer and bleeding may occur due to poor epithelisation of the fistulous tract which makes the diagnosis of double pylorus important. In most cases, double pylorus responds well to antipeptic ulcer medical therapy such as PPIs, regardless of whether the fistula remains patent or closes spontaneously. Surgical intervention is indicated for patients with refractory symptoms like recurrent ulcers and recurrent bleeding episodes despite being on adequate medical therapy with PPIs. ${ }^{23}$

\section{Learning points}

- The 'double pylorus' is a rare condition due to a gastroduodenal fistula extending from the gastric antrum to the duodenal bulb and may be congenital or acquired.

- Acquired cases can occur as a complication of chronic peptic ulcer disease or in gastric cancer.

- In most cases, double pylorus responds well to antipeptic ulcer medical therapy such as proton pump inhibitors, regardless of whether the fistula remains patent or closes spontaneously.

- The surgical intervention is indicated for patients with refractory symptoms like recurrent ulcers and recurrent bleeding episodes despite being on adequate medical therapy. 
Contributors SST was involved in writing, editing and review of the article. JS was involved in editing and critical review of the article.

Funding The authors have not declared a specific grant for this research from any funding agency in the public, commercial or not-for-profit sectors.

Competing interests None declared.

Patient consent Obtained.

Provenance and peer review Not commissioned; externally peer reviewed.

\section{REFERENCES}

1 Fousekis F, Aggeli P, Kotsaftis P, et al. Double pylorus: report of a case with endoscopic follow-up and review of the literature. Gastroenterology Res 2018; 11:154-6.

2 Arhan $M, 0 z t a s$ E, lbis $M$, et al. A rare endoscopic finding: acquired double pylorus. Surg Endosc 2010;24:244-5.

3 Hu TH, Tai DI, Changchien CS, et al. Double pylorus: report of a longitudinal follow-up in two refractory cases with underlying diseases. Am J Gastroenterol 1995:90:815-8.

Copyright 2018 BMJ Publishing Group. All rights reserved. For permission to reuse any of this content visit http://group.bmj.com/group/rights-licensing/permissions.

BMJ Case Report Fellows may re-use this article for personal use and teaching without any further permission.

Become a Fellow of BMJ Case Reports today and you can:

- Submit as many cases as you like

- Enjoy fast sympathetic peer review and rapid publication of accepted articles

- Access all the published articles

Re-use any of the published material for personal use and teaching without further permission

For information on Institutional Fellowships contact consortiasales@bmjgroup.com

Visit casereports.bmj.com for more articles like this and to become a Fellow 